\title{
Penerapan materi ilmu pengetahuan alam pada serious game sosialisasi mitigasi bencana berbasis model teori aktivitas dan taksonomi bloom
}

\section{The application of natural sciences material in serious game for mitigation disasters socialization based on theory model activity and bloom's taxonomy}

\author{
Fresy Nugroho a, Eko Mulyanto Yuniarno ${ }^{b}$, Mochamad Hariadi c \\ a,b,c Teknik Elektro, Institut Teknologi Sepuluh Nopember, Surabaya, Indonesia \\ a Teknik Informatika, Universitas Islam Negeri Maulana Malik Ibrahim, Malang, Indonesia \\ email:afresy14@mhs.ee.its.ac.id,bekomulyanto@ee.its.ac.id, cmochar@ee.its.ac.id
}

\begin{tabular}{l}
\hline I N F O A R T I K E L \\
\hline Sejarah artikel: \\
Menerima 25 Februari 2019 \\
Revisi 13 Mei 2019 \\
Diterima 20 Mei 2019 \\
Online 26 Juni 2019 \\
\hline Kata kunci: \\
Ilmu Pengetahuan Alam \\
Serious Game \\
Taksonomi Bloom \\
Model Teori Aktivitas \\
Sosialisasi mitigasi bencana \\
\hline Keywords: \\
Science \\
Serious Game \\
Bloom's Taxonomy \\
Activity Theory Model \\
Disaster mitigation socialization \\
\hline Style APA dalam menyitasi \\
artikel ini: \\
Nugroho, F., Yuniarno, E. M., \\
\& Hariadi, M. (2019). \\
Penerapan materi ilmu \\
pengetahuan alam pada \\
serious game sosialisasi \\
mitigasi bencana berbasis \\
model teori aktivitas dan \\
taksonomi bloom. Register: \\
Jurnal Ilmiah Teknologi Sistem \\
Informasi, 5(2), 106-117.
\end{tabular}

\section{ABSTRAK}

Penelitian ini merupakan kombinasi antara materi hiburan dan pendidikan untuk meningkatkan pemahaman tentang bencana alam, terutama bencana vulkanik. Desain yang diusulkan menggabungkan model Teori Aktivitas dan Taksonomi Bloom. Metode ini dapat menghemat biaya dan waktu. Titik fokus dari penelitian ini adalah materi Ilmu Pengetahuan Alam berdasarkan kurikulum 2013. Penelitian ini adalah langkah pertama untuk mengintegrasikan unsur-unsur pendidikan, hiburan, dan teknologi sebagai media pembelajaran untuk pengurangan risiko bencana. Kemampuan siswa dieksplorasi dengan menerapkan tiga aspek pembelajaran. Hasil tes menunjukkan bahwa kemampuan siswa meningkat $14,2 \%$ setelah bermain sepuluh kali dan meningkat menjadi $29,48 \%$ setelah siswa bermain 25 kali, dibandingkan dengan skor pretest.

\section{ABSTRACT}

This research is a combination of entertainment and education material to improve an understanding of natural disasters, especially volcanic eruptions. The proposed design combines Bloom's Taxonomy and Activity Theory models. The method reduces cost and time. The focal point of the research is the natural sciences material based on the 2013 curriculum. This research is the first step to integrate the elements of education, entertainment, and technology as a learning media for disaster risk reduction students' abilities explored by applying three aspects of learning. The test results show that students' abilities are increased by $14.2 \%$ after play for ten times and increased to $29.48 \%$ after playing for 25 times, compared to the pretest scores.

(c) 2019 Register: Jurnal IImiah Teknologi Sistem Informasi. Semua hak cipta dilindungi undang-undang.

\section{Pendahuluan}

Pengurangan Risiko Bencana (PRB) yang berkaitan dengan bidang pendidikan perlu menjadi program prioritas dalam sektor pendidikan formal. Hal ini sesuai dengan yang tercantum dalam Hyogo Framework for Action (HFA) dan telah diusulkan dalam Sendai Framework for Disaster Risk Reduction (SFDRR) 2015-2030. Beberapa negara telah menerapkan PRB melalui kurikulum sekolah, di antaranya Penerapan materi ilmu pengetahuan alam pada serious game sosialisasi mitigasi ... $\quad$ http://doi.org/10.26594/register.v5i2.1479 (c) 2019 Register: Jurnal IImiah Teknologi Sistem Informasi. Semua hak cipta dilindungi undang-undang. 
Oregon, Texas, dan Filipina. Sejak 2009, Oregon telah mengembangkan PRB melalui kurikulum pendidikan berdasarkan standar konten ilmu sains. Kemudian, diperbaiki pada 2014 dan diterapkan pada seluruh jenjang pendidikan (nextgenscience, 2013). Texas mengembangkan penerapan PRB berbasiskan pengetahuan dan keterampilan untuk semua jenjang pendidikan. Filipina membentuk kurikulum dengan fokus penanganan bencana dan dikembangkan sebagai program $K$ hingga 12 tahun, menjadikannya sebagai negara yang lebih kompetitif dalam menangani bencana (Doroteo, 2015).

Indonesia masih memiliki masalah utama, yaitu rendahnya kinerja penanganan bencana, rendahnya perhatian mengenai mitigasi bencana, dan masih lemahnya peran sekolah dalam pengenalan pendidikan mitigasi bencana. UNISDR atau nama lain dari United Nations Office for Disaster Risk Reduction (UNDRR), mengkritik kebijaksanaan pencegahan dan perlindungan bencana alam di Indonesia. Menurut mereka, kelemahan tersebut terdapat dalam beberapa hal, antara lain koordinasi antarkementerian, anggaran penanggulangan bencana alam yang hanya 0,699\% dari anggaran nasional, dan analisis risiko bencana (Wszolek \& Pfeiffer, 2015). Situasi ini memperparah mitigasi bencana di Indonesia. Kondisi ini diperburuk dengan rendahnya penggunaan teknologi dan minimnya pendidikan kesiapsiagaan bencana.

Sementara itu, penerapan teknologi komputer untuk ujian nasional mulai meningkat. Maka, sudah selayaknya jika sosialisasi mitigasi PRB dilakukan melalui teknologi komputer. Salah satu aplikasi teknologi yang potensial untuk penerapan PRB adalah Serious Game. Beberapa studi mendorong penggunaan Serious Game untuk belajar dan memperoleh pengalaman. Keluwesan Serious Game mendukung desain instruksional pada siswa melalui peningkatan motivasi, tantangan, serta pembelajaran prinsip-prinsip yang harus dikuasai (Hamlen, 2011; Pourabdollahian, Taisch, \& Kerga, 2012).

Berdasarkan temuan yang telah diuraikan tersebut, makalah ini menggabungkan desain Serious Game Sosialisasi Mitigasi Bencana berbasis Teori Aktivitas dengan materi sains. Maka, kontribusi penelitian ini adalah: 1) Penelitian ini mengusulkan agar pendidikan mengenai PRB dapat dilakukan melalui penerapan kurikulum sejak tingkat sekolah dasar, berupa Serious Game yang berisi materi sains. Sebagai fokus awal, kami menyarankan materi sains yang digunakan merupakan materi Ilmu Pengetahuan Alam, dengan subbab bumi dan antariksa untuk kelas empat sekolah dasar.; 2) Serious Game yang diajukan dalam penelitian ini berbasis model Teori Aktivitas (Carvalho, 2016; Callaghan, McShane, \& Eguíluz, 2018) dan melingkupi tiga ranah Taksonomi Bloom (Ahmad \& Hussin, 2017; Haring, Warmelink, Valente, \& Roth, 2018).

\section{State of the Art}

Subbab ini menguraikan perkembangan terakhir yang mendasari penelitian ini. Terdapat tiga pilar utama, yaitu uraian tentang Serious Games Digital karena pesatnya perkembangan teknologi digital, dilanjutkan dengan model Serious Game yang fokus pada sisi mekaniknya, dan terakhir, disampaikan pula penerapan Taksonomi Bloom di bidang e-learning.

\subsection{Serious Game Digital}

Serious Game Digital mencapai titik perkembangan yang menggembirakan. Pasalnya, permainan ini mampu menyeimbangkan fungsi edukasi, sarana berlatih, sekaligus hiburan sehingga merupakan terobosan untuk mendukung pembelajaran yang efektif dan efisien (Carvalho, 2016; Hanes \& Stone, 2018; Gao, Ma, Guo, Wang, \& Wang, 2019).

Pendekatan baru Serious Game yang diajukan mempertimbangkan dinamika aksi dan motivasi pemain game berbasiskan teori game flow. Hasil penelitian dibuktikan berdasarkan penelitian kuantitatif, dengan melakukan tujuh simulasi dan melibatkan 100.000 iterasi untuk membuktikan kestabilan model yang diajukan. Dengan pendekatan ini, dimungkinkan untuk menunjukkan hubungan antara variabel game dan pemahaman bagaimana proses belajar dalam Serious Game serta dapat digunakan sebagai acuan dalam mendesain Serious Game (Westera, 2017; Yuhana, Yuniarno, Nugroho, Rochimah, \& Purnomo, 2017).

\section{2. $\quad$ Model Teori Aktivitas dalam Serious Game}

Dalam penelitian lanjutan tentang Serious Game, dikembangkan kerangka konseptual model Serious Game berbasis model Teori Aktivitas. Penelitian ini menyempurnakan beberapa kerangka yang telah

Penerapan materi ilmu pengetahuan alam pada serious game sosialisasi mitigasi ... $\quad$ http://doi.org/10.26594/register.v5i2.1479 (c) 2019 Register: Jurnal IImiah Teknologi Sistem Informasi. Semua hak cipta dilindungi undang-undang. 
dikembangkan sebelumnya, yaitu Serious Game berbasis arsitektur orientasi pelayanan. Kerangka berbasis model aktivitas menguraikan secara detail hingga tingkat mekaniknya. Pendekatan yang diajukan ini dievaluasi dengan metode analisis arsitektur trade-off dan diterapkan pada Serious Game. Hasil desain Serious Game mampu melibatkan unsur edukasi dan hiburan dengan porsi seimbang serta waktu pembuatan yang cepat. Efek berikutnya berupa penurunan biaya produksi dan peningkatan kualitas Serious Game. Model ini memiliki aktivitas utama, yaitu aktivitas bermain, belajar, dan instruksional. Masing-masing aktivitas terdiri dari tiga komponen, yaitu aksi, perangkat, dan tujuan (Carvalho, 2016; Callaghan, McShane, \& Eguíluz, 2018).

\subsection{Taksonomi Bloom}

Taksonomi Bloom terdiri dari pengetahuan, pemahaman, aplikasi, analisis, sintesis, dan evaluasi. Selanjutnya, Taksonomi Bloom direvisi dengan menambahkan beberapa komponen, seperti perubahan istilah pada tiap tingkat, pengaturan tingkat yang lebih detail dan penambahan jumlah dimensi. Perubahan ini telah diterapkan pada desain e-learning yang mengandung instruksi secara online. Elearning ini berbasis objek dan keluaran pembelajaran. Contoh yang diajukan sebagai penerapan adalah tentang pembelajaran tata bahasa. Terkait hal tersebut, desain yang diajukan sudah mempertimbangkan tiga aspek pembelajaran secara terpadu, yaitu aspek kognitif, afektif, dan psikomotorik pemain (Ahmad \& Hussin, 2017; Haring, Warmelink, Valente, \& Roth, 2018).

\subsection{Upaya Sosialisasi Mitigasi Bencana yang Telah Dilakukan}

Beberapa terobosan dalam mengenalkan bencana telah dilakukan, misalnya berupa game tentang gempa bumi untuk anak autis (Kurniawan, Mahtarami, \& Rakhmawati, 2017). Begitu juga prediksi hotspot tentang aktivitas gempa bumi menggunakan metode Pattern Informatics (Wibowo, Insani, \& Suwardi, 2017).

\section{Metode Penelitian}

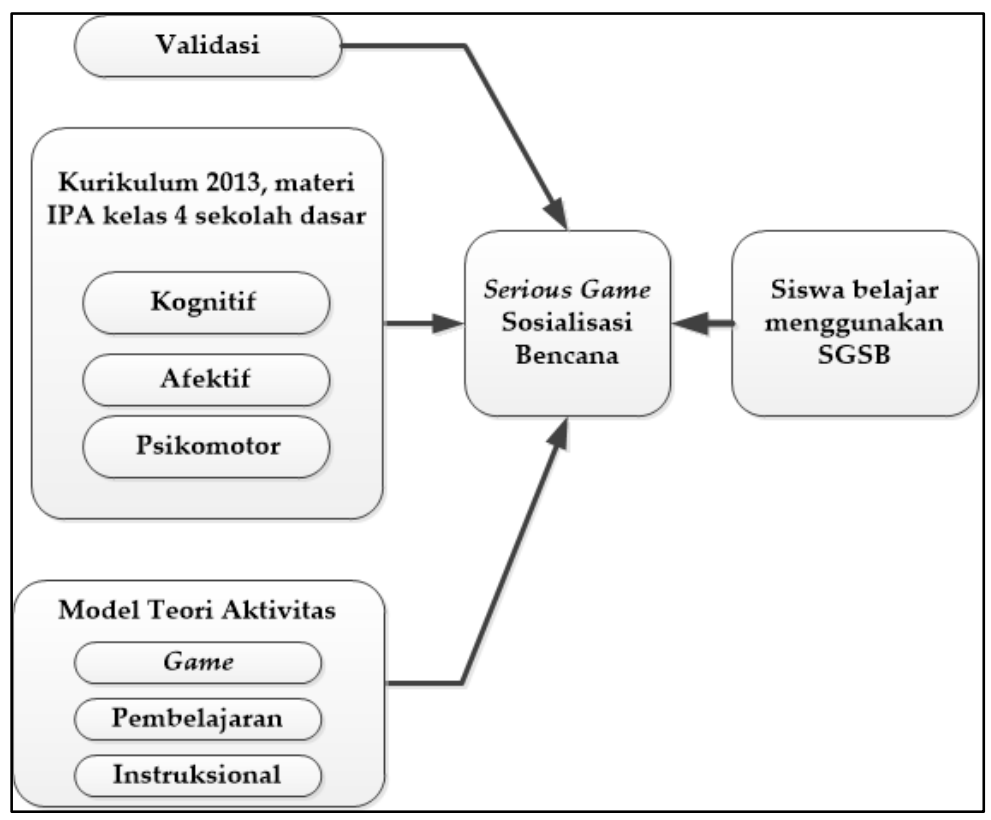

Gambar 1. Blok diagram penelitian yang diusulkan

Prosedur riset dibangun dalam lima tahapan seperti yang disajikan pada Gambar 1, di antaranya:

1) Identifikasi kurikulum 2013, materi sains untuk kelas 4 (empat) Sekolah Dasar (SD), yaitu materi ajar Ilmu Pengetahuan Bumi dan Antariksa (IPBA). Kurikulum yang diacu melibatkan tiga ranah Taksonomi Bloom, terdiri dari ranah kognitif, afektif, dan psikomotorik. Materi IPBA difokuskan pada satu jenis bencana, yaitu bencana gunung meletus.

Tabel 1 menyajikan jenis kompetensi IPA SD kelas 4 yang digunakan. Kompetensi dibedakan menjadi dua jenis, yakni standar kompetensi dan kompetensi dasar. Standar kompetensi terdiri dari a) mengerti transformasi bumi dan antariksa, b) mengerti transformasi wilayah dan pengaruhnya terhadap daerah sekitar, serta c) mengerti asosiasi antara sumber daya semesta 
dan daerah sekitar. Standar kompetensi (a) diberikan pada semester satu, sedangkan standar kompetensi (b) dan (c) diberikan pada semester dua.

Identifikasi pemahaman siswa bidang IPA kelas 4 untuk mengetahui jenjang penguasaan pelajar dilihat dari aspek kognitif meliputi jenjang ingatan $\left(C_{1}\right)$, pengertian $\left(C_{2}\right)$, dan penerapan $\left(C_{3}\right)$. Sementara, untuk mengetahui tingkat pemahaman siswa pada ranah afektif, meliputi perilaku ingin tahu $\left(A_{1}\right)$, mendapatkan sesuatu yang baru $\left(A_{2}\right)$, kolaborasi $\left(A_{3}\right)$, pantang menyerah $\left(A_{4}\right)$, bertanya jika mengalami kesulitan $\left(A_{5}\right)$, introspeksi $\left(A_{6}\right)$, konsekuen $\left(A_{7}\right)$, berani menyampaikan pendapat $\left(A_{8}\right)$, dan kedisiplinan $\left(A_{9}\right)$. Kemudian, cara mengetahui jenjang pengertian pelajar pada aspek psikomotorik, dijabarkan sebagai kecakapan mengamati $\left(P_{1}\right)$, teliti dan teratur $\left(P_{2}\right)$, mengelompokkan $\left(P_{3}\right)$, melakukan estimasi $\left(P_{4}\right)$, mendesain $\left(P_{5}\right)$, melaksanakan riset $\left(P_{6}\right)$, meringkas $\left(P_{7}\right)$, mengimplementasikan $\left(P_{8}\right)$, serta melakukan sosialisasi $\left(P_{9}\right)$. Penjabaran indikator tiap standar kompetensi pelajar diperlihatkan dalam Tabel 2.

Tabel 1. Penjabaran kompetensi IPA SD kelas 4

Standar Kompetensi

a. Mengerti transformasi bumi dan antariksa

b. Mengerti transformasi wilayah dan pengaruhnya terhadap daerah sekitar

c. Mengerti asosiasi antara sumber daya semesta dan daerah sekitar

\section{Kompetensi Dasar}

1. Mendeskripsikan transformasi permukaan bumi

2. Menguraikan ketampakan bumi setiap hari dan posisi bulan

1. Menjelaskan penyebab transformasi lingkungan (cahaya matahari, hujan, angin, dan gelombang pasang surut)

2. Menggambarkan pengaruh transformasi lingkungan terhadap bumi (banjir, abrasi, longsor, dan erosi)

3. Menceritakan cara mencegah kerusakan lingkungan

1. Menjelaskan asosiasi antara sumber daya semesta dan daerah sekitar

2. Merumuskan asosiasi antara sumber daya semesta dan teknologi 3. Menjelaskan dampak ekploitasi alam terhadap pelestarian dunia

Tabel 2. Kisi-kisi pemahaman siswa terhadap materi

\begin{tabular}{|c|c|c|c|c|}
\hline & Indikator materi pembelajaran dalam Serious Game & $\begin{array}{c}\text { Kognitif } \\
(30 \%)\end{array}$ & $\begin{array}{c}\text { Afektif } \\
(30 \%)\end{array}$ & $\begin{array}{l}\text { Psikomotorik } \\
(40 \%)\end{array}$ \\
\hline 1 & Identifikasi dampak erupsi gunung berapi & $C_{1}$ & & \\
\hline 2 & Identifikasi langkah mitigasi bencana & $C_{1}$ & & \\
\hline 3 & Menguraikan perubahan lingkungan fisik & $C_{2}$ & & \\
\hline 4 & Menjelaskan penyebab gunung meletus & $C_{2}$ & & \\
\hline 5 & Menjelaskan berbagai jenis gunung api & $C_{2}$ & & \\
\hline 6 & Proses erupsi gunung api & $C_{3}$ & & \\
\hline 7 & Mengulang-ulang percobaan & & $A_{1}$ & \\
\hline 8 & Terlibat dalam tugas & & $A_{2}$ & \\
\hline 9 & Saling membantu dalam simulasi & & $A_{3}$ & \\
\hline 10 & Berpikir bebas & & $A_{4}$ & \\
\hline 11 & Bertanya jika mengalami kesulitan & & $A_{5}$ & \\
\hline 12 & Indikator materi pembelajaran dalam Serious Game & & $A_{6}$ & \\
\hline 13 & Konsekuen & & $A_{7}$ & \\
\hline 14 & Menerapkan percobaan yang aman & & $A_{8}$ & \\
\hline 15 & Menyelesaikan lembar pertanyaan dan tugas & & & $P_{1}$ \\
\hline 16 & Kedisiplinan & & & $P_{2}$ \\
\hline 17 & Memisahkan jenis gunung api & & & $P_{3}$ \\
\hline 18 & Menata puzzle gunung api & & & $P_{4}$ \\
\hline 19 & $\begin{array}{l}\text { Mengestimasi transformasi yang mungkin terjadi saat } \\
\text { eksperimen }\end{array}$ & & & $P_{5}$ \\
\hline 20 & Merencanakan simulasi untuk mengurangi dampak bencana & & & $P_{6}$ \\
\hline 21 & Merencanakan eksperimen simulasi letusan gunung api & & & $P_{7}$ \\
\hline 22 & Melaksanakan percobaan miniatur erupsi gunung api & & & $P_{8}$ \\
\hline 23 & Menyampaikan hasil simulasi sederhana mitigasi bencana & & & $P_{9}$ \\
\hline
\end{tabular}

Penerapan materi ilmu pengetahuan alam pada serious game sosialisasi mitigasi ... 
1) Identifikasi model Teori Aktivitas saat bermain game. Model Teori Aktivitas digunakan untuk menyusun gameplay dari Serious Game Sosialisasi Mitigasi Bencana yang dibuat.

2) Desain Serious Game Sosialisasi Mitigasi Bencana (SGMSB).

3) Validasi terhadap SGMSB. Validator terdiri dari ahli multimedia, guru, dan siswa. Ahli multimedia bertujuan memvalidasi dari sisi multimedia, antara lain: kemudahan informasi, kemudahan bermain, tata letak, huruf yang digunakan, warna, dan navigasi. Validasi dari sisi materi belajar dilakukan oleh kepala sekolah dan guru pengajar kelas 1 hingga 4. Validasi berdasarkan sisi pengguna dilakukan oleh lima siswa yang dipilih secara acak. Komponen validasi siswa lebih difokuskan pada kenyamanan saat bermain, kesenangan siswa, ketertarikan pada permainan, materi, dan kemudahan dalam menangkap tugas yang harus diselesaikan.

4) Uji coba pada siswa kelas 4 SD.

Sejumlah 30 siswa SD di Jawa Timur menjadi responden untuk tes berikutnya. Responden didasarkan pada jenis kelamin, terdiri atas 17 murid laki-laki dan 13 murid perempuan. Responden berasal dari kelas 4 dan berumur 10 tahun.

\section{Hasil dan Pembahasan}

Desain gameplay SGMSB ditunjukkan dalam Gambar 2. Berdasarkan Gambar 2, setelah pemain masuk ke permainan, dari sisi bermain, ia diminta melakukan aksi berupa kustomisasi atau memilih model avatar yang akan diperankan. Perangkat yang tersedia adalah avatar yang akan dimainkan dengan tujuan melakukan konfigurasi permainan.

Selanjutnya, pemain memasuki tahap pendahuluan. Pada tahap ini, berdasarkan model Teori Aktivitas, pemain akan melakukan sisi bermain, yang terdiri dari aksi, yaitu melihat. Perangkat dalam permainan berupa informasi yang disajikan pada pemain, dengan tujuan pemain mempelajari antarmuka yang ada dalam permainan. Pada tahap berikutnya, pemain akan dihadapkan pada pilihan untuk memilih misi baru atau tidak. Jika memilih misi baru, pemain akan memainkan puzzle. Jika tidak memilih misi baru, permainan akan memberikan saran, selanjutnya mengarahkan pemain untuk memainkan puzzle.

Selanjutnya, penghargaan. Permainan akan memberi penghargaan berupa penambahan nilai, penambahan kemampuan pemain, serta bonus yang lain. Setelah menerima penghargaan, pemain dihadapkan pada pilihan bermain puzzle yang sama atau puzzle jenis lain. Jika memilih main lagi untuk jenis puzzle yang sama, pemain akan memiliki kesempatan meningkatkan penghargaan yang telah diperoleh hingga mencapai nilai maksimal. Kalau pemain memilih untuk memainkan jenis puzzle yang lain, ia berkesempatan untuk meningkatkan kemampuan dalam tahapan sosialisasi.

Berdasarkan model Teori Aktivitas, pemain berada pada tiga sisi sekaligus, yaitu sisi bermain, belajar, dan instruksi intrinsik. Pada sisi bermain, aksi yang dilakukan pemain adalah mencari bantuan. Perangkat yang disediakan permainan adalah tutorial permainan dengan tujuan mempelajari antarmuka permainan. Dari sudut pandang belajar, aksi yang dilakukan pemain adalah mengamati. Perangkat yang disediakan permainan berupa saran untuk menuntaskan permainan, dengan tujuan pemain mengingat tutorial yang diberikan. Kemudian, instruksi intrinsik, yaitu pemain mendemonstrasikan dengan perangkat berupa saran untuk dipenuhi, yang bertujuan menyediakan petunjuk belajar pada pemain. Begitu seterusnya hingga permainan selesai.

Pemetaan tiga ranah Taksonomi Bloom pada model Teori Aktivitas diuraikan dalam subbab 2.2, yang mana model ini memiliki aktivitas utama, yaitu: aktivitas bermain, belajar, dan instruksional. Masing-masing aktivitas terdiri dari tiga komponen, yaitu: aksi, perangkat, dan tujuan (Carvalho, 2016). Maka, perlu direncanakan implementasi tiga ranah sebagaimana terdapat dalam Tabel 1, pada model Teori Aktivitas. Pemain atau siswa dalam hal ini diharapkan melakukan aksi, agar tercapai tujuan pembelajaran. Gambar 3 memperlihatkan pemetaan tiga ranah Taksonomi Bloom pada model Teori Aktivitas. Aksi pemain atau siswa diberi warna merah.

Pemetaan gameplay awal bermain, pada model Teori Aktivitas dan implementasi tiga ranah Taksonomi Bloom diperlihatkan dalam Gambar 4. Pemain atau siswa mengawali permainan dengan 
melakukan kustomisasi avatar (karakter yang dimainkan), yang bertujuan melakukan konfigurasi Serious Game, dilanjutkan dengan melihat dan mempelajari cara bermain, cara penilaian, serta mempelajari antarmuka Serious Game. Aksi yang dilakukan pemain merupakan indikator A4 (perilaku berpikir bebas), pengetahuan tentang dampak erupsi dan mitigasi (C1), dan perubahan lingkungan fisik, penyebab gunung meletus, dan jenis gunung berapi (C2).

Pada langkah selanjutnya, pemain diberi pilihan untuk memilih misi baru atau tidak. Walaupun memilih tidak, pemain tetap dipaksa untuk bermain puzzle berupa saran dan mengembalikan alur permainan pada jalur utama permainan. Dari sisi bermain, aksi yang dilakukan pemain sudah dapat dianggap sebagai penerapan A5. Pada segi belajar, siswa sudah berada pada ranah C1 dan C2. Untuk tahap instruksi, pemain diharapkan mampu menerapkan C3. Kemudian saat bermain puzzle, sisi bermain terdiri dari C1, A2, P1, P2, P3, dan P4. Sudut pandang belajar, siswa melakukan A1, A2, dan A3. Dan instruksi merupakan implementasi A4, A8, P5, P6, P7, dan P8 sebagaimana diperlihatkan dalam Gambar 5.

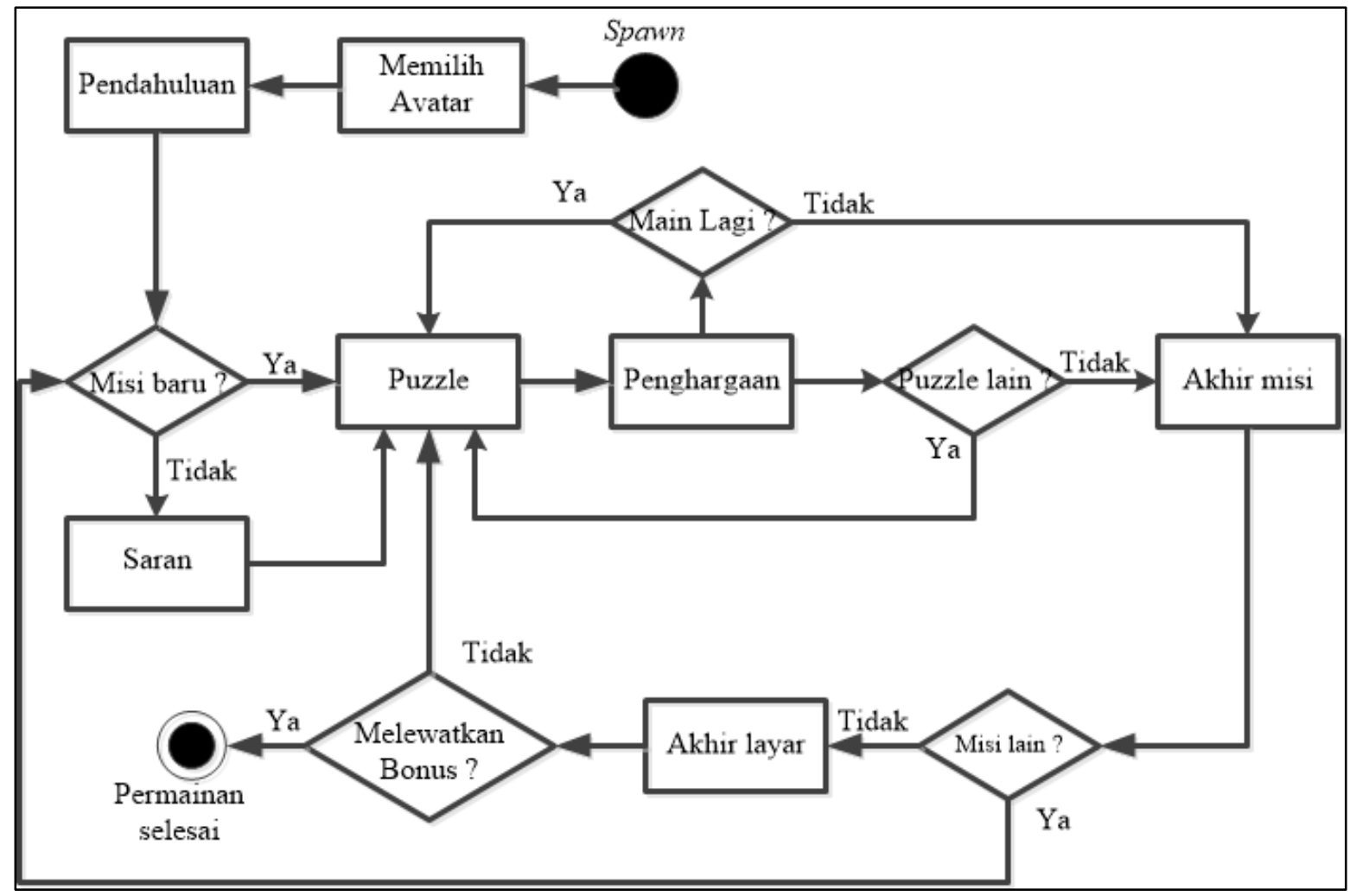

Gambar 2. Gameplay SGMSB

\begin{tabular}{|c|c|c|}
\hline \multirow{3}{*}{ 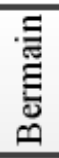 } & Aksi & Kognitif, Afektif dan Psikomotor \\
\hline & Perangkat & Disediakan dalam serious game \\
\hline & Tujuan & Memberikan nuansa bahagia \\
\hline \multirow{3}{*}{ 离 } & Aksi & Kognitif, Afektif dan Psikomotor \\
\hline & Perangkat & Disediakan dalam serious game \\
\hline & Tujuan & $\begin{array}{l}\text { Memberikan pengetahuan, pemahaman, penerapan, } \\
\text { membentuk sikap dan melatih perilaku }\end{array}$ \\
\hline \multirow{3}{*}{ 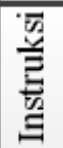 } & Aksi & Kognitif, Afektif dan Psikomotor \\
\hline & Perangkat & Disediakan dalam serious game \\
\hline & Tujuan & Menyediakan petunjuk belajar \\
\hline
\end{tabular}

Gambar 3. Pemetaan Taksonomi Bloom pada model Teori Aktivitas

Dalam Gambar 6, pemain diberi penghargaan. Pada sisi bermain, aksi siswa berupa A6. Dilihat dari sisi belajar, aksi yang dilakukan siswa termasuk dalam ranah A5, A7, dan P9. Sementara pada sisi instruksi, aksi siswa termasuk dalam ranah P9. Kemudian, siswa diberikan pilihan apakah akan 
bermain puzzle lain atau tidak. Jika siswa memilih tidak, misi berakhir. Pada kondisi ini, aksi siswa merupakan A6.

Contoh layar SGMSB diperlihatkan dalam Gambar 7. Dalam tampilan tersebut, terdapat parameter untuk bermain game, yang terdiri dari parameter kesehatan, waktu bermain yang tersedia, skor, pertanyaan, pilihan jawaban, dan navigasi ke permainan berikutnya.

Dalam Gambar 8, tampak hasil validasi sebelum SGMSB diuji coba pada siswa. Pertanyaan untuk validasi terdiri dari 20 pertanyaan (diperlihatkan sebagai sumbu $x$ ). Rentang nilai antara 0 hingga 100 (diperlihatkan sebagai sumbu y). Pertanyaan yang diajukan berbeda untuk tiap kelompok validator. Dari sisi ahli multimedia, terdapat satu poin pertanyaan yang bernilai 60 . Rata-rata hasil validasi dari sisi multimedia berada pada nilai 70. Maka, hasil yang diperoleh menunjukkan bahwa desain SGMSB layak digunakan.

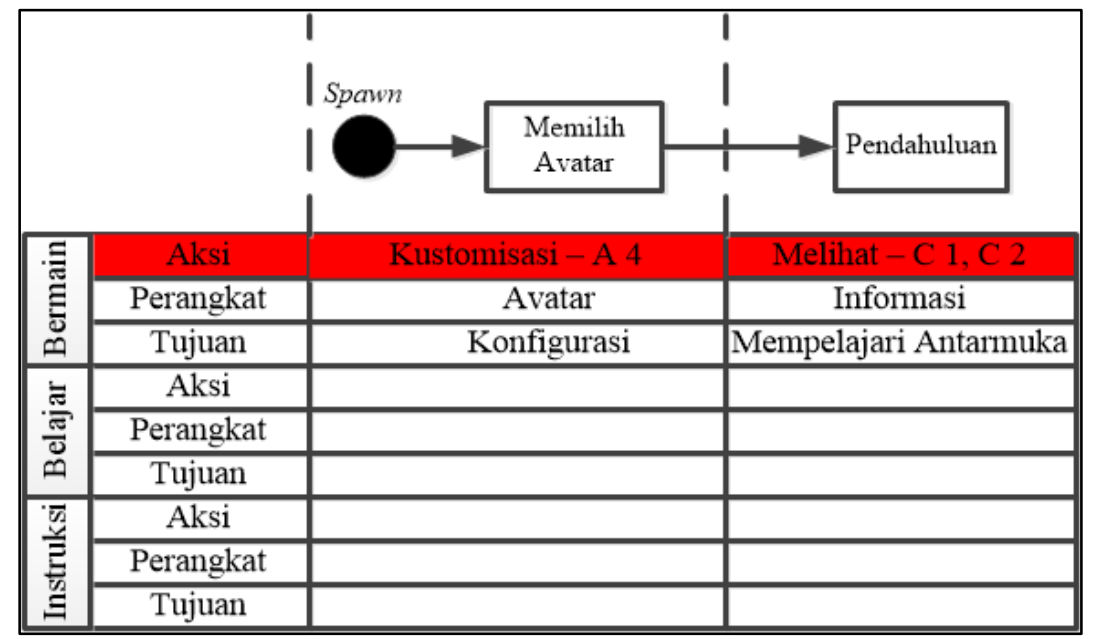

Gambar 4. Pemetaan Taksonomi Bloom pada model Teori Aktivitas

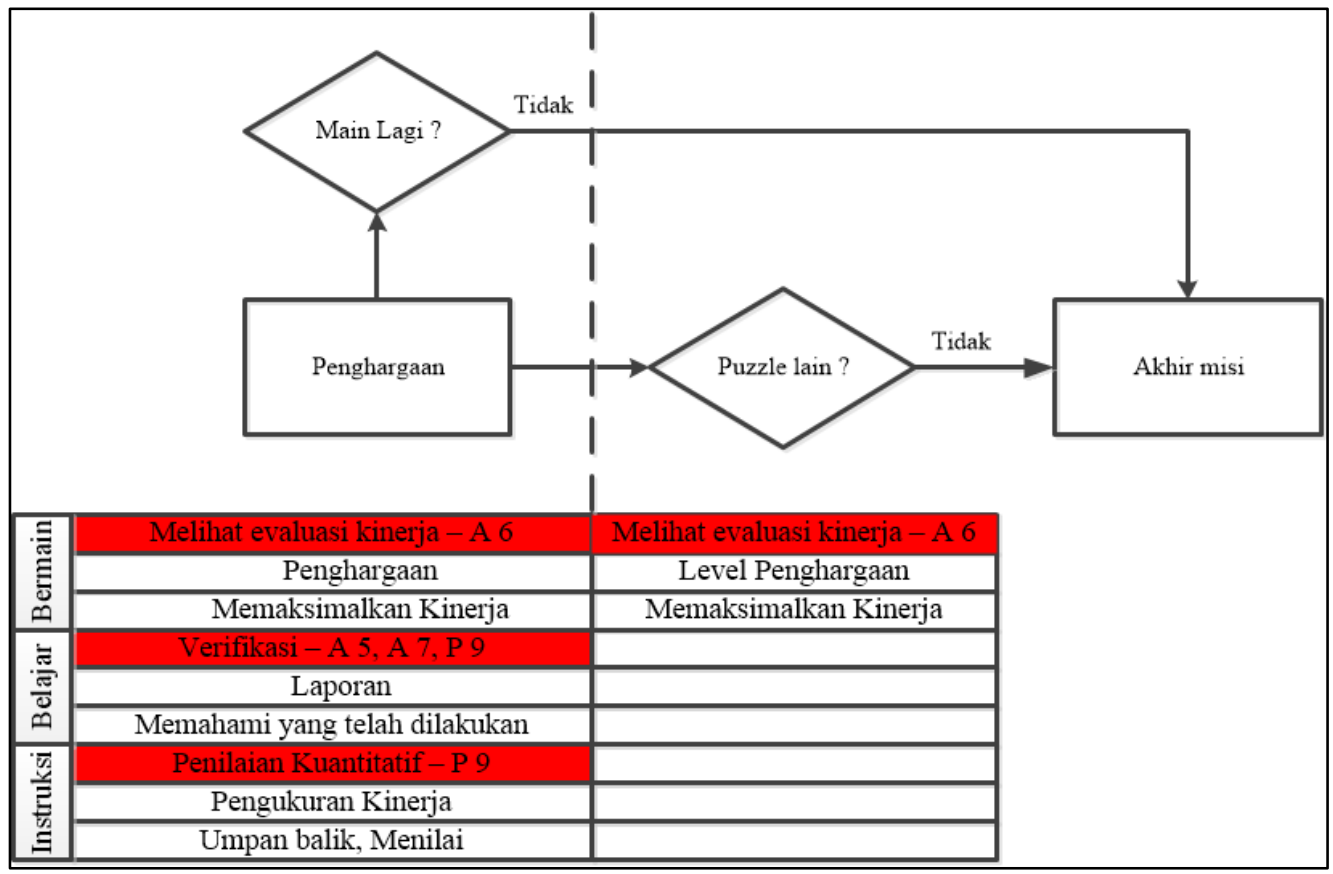

Gambar 5. Penerapan indikator dalam Tabel 1 pada gameplay SGMSB

Dari sisi materi pembelajaran, rata-rata nilai yang diperoleh adalah 70 hingga 80 . Hal ini menunjukkan bahwa pertanyaan-pertanyaan yang diajukan dalam SGMSB sudah memenuhi standar kurikulum nasional dan sudah meliputi tiga ranah Taksonomi Bloom untuk siswa kelas 4 SD. Validasi dari siswa memberikan nilai 75 hingga 80 . Hal ini menunjukkan bahwa SGMSB memberikan kenyamanan, kesenangan, dan kemudahan bermain.

Uji coba pada 30 siswa diperlihatkan dalam Gambar 9. Sumbu $x$ merupakan jumlah siswa dan sumbu $y$ merupakan skor yang dicapai siswa dengan rentang nilai 0 hingga 100 . Uji coba terdiri dari 
tiga tahap, yaitu: pretest, tes setelah bermain 10 kali, dan tes kedua setelah bermain 25 kali. Kuesioner yang diajukan saat prates dan setelah bermain terdiri atas 20 pertanyaan. Prates digunakan untuk mengetahui pemahaman siswa tentang bencana alam sebelum bermain SGMSB, dalam hal ini bencana gunung meletus. Tes untuk mengetahui pemahaman siswa dilakukan dua kali, yaitu setelah bermain 10 kali dan setelah bermain 25 kali. Dalam Gambar 9, terdapat peningkatan skor dari tiap siswa.

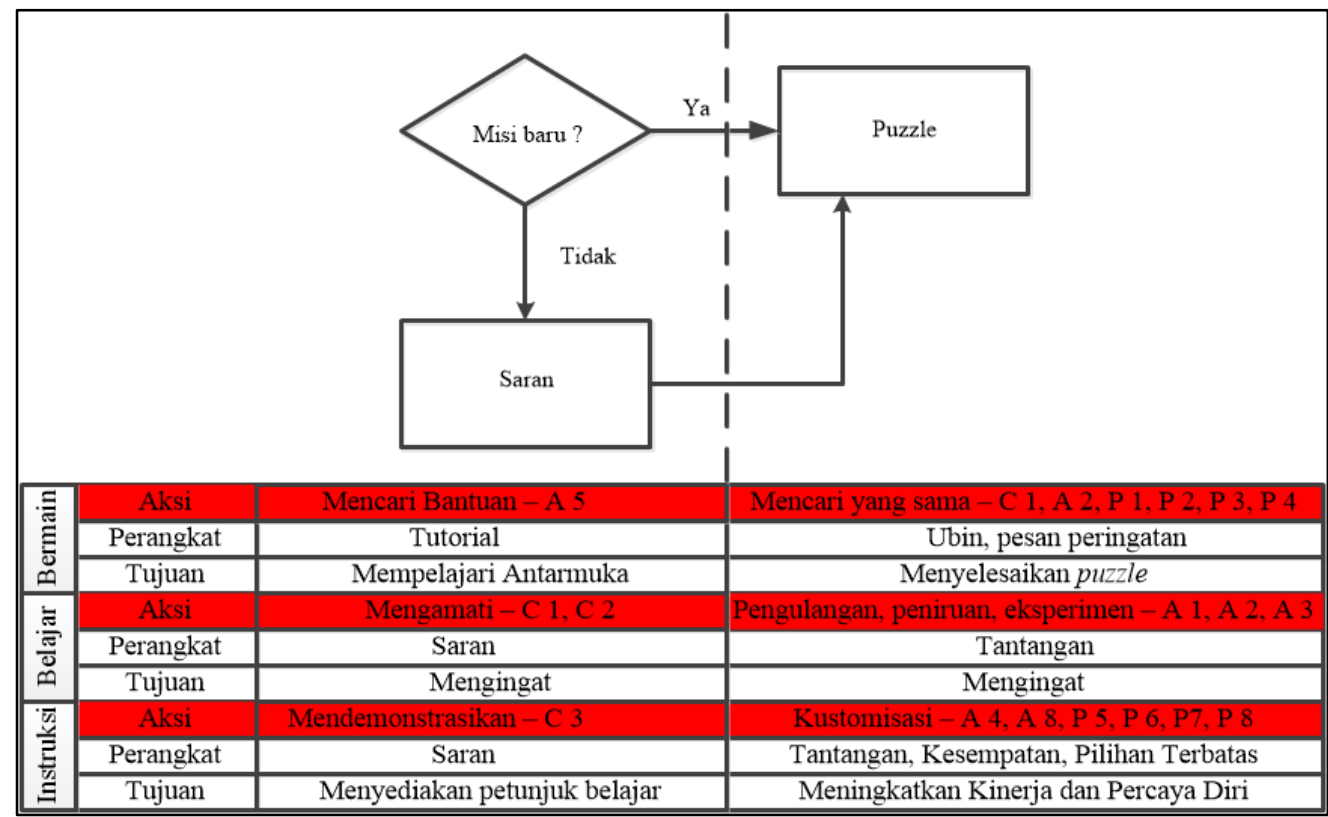

Gambar 6. Penerapan indikator dalam Tabel 1 pada gameplay SGMSB pada langkah selanjutnya

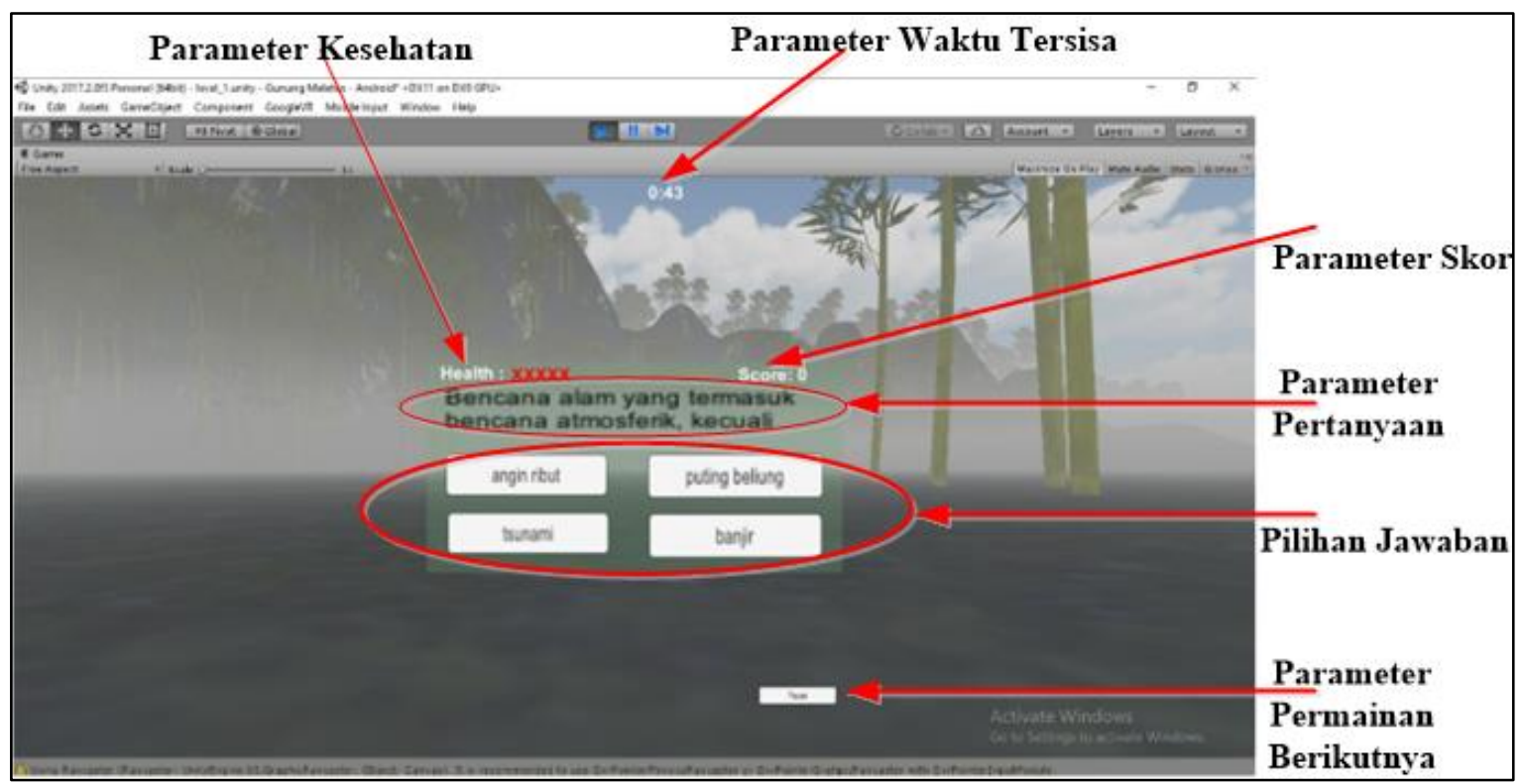

Gambar 7. Ilustrasi Serious Game Sosialisasi Mitigasi Bencana (SGMSB)

Nilai rata-rata siswa saat pretest adalah 58,87. Setelah bermain sebanyak 10 kali, nilai rata-rata siswa adalah 66,93. Setelah bermain $25 \mathrm{kali}$, pencapaian siswa meningkat menjadi 75,66. Hal ini menyatakan bahwa siswa menikmati permainan yang disuguhkan dan siswa mengalami peningkatan pemahaman tentang materi yang disajikan. Pencapaian nilai rata-rata siswa diperlihatkan dalam Gambar 10.

Peningkatan pemahaman tiap siswa dapat dipandang sebagai selisih. Hal ini diperlihatkan dalam Gambar 11. Peningkatan kemampuan siswa setelah bermain 10 kali dinyatakan sebagai Delta 1. Dan peningkatan skor siswa setelah bermain 25 kali dinyatakan sebagai Delta 2. Sumbu $x$ merupakan jumlah siswa, dan sumbu y merupakan skor yang dicapai siswa. Dari selisih skor ini, rata-rata kemampuan siswa meningkat sebesar 14,2\% setelah bermain 10 kali dibandingkan skor pretes. Pada 
Delta 2, yaitu setelah siswa bermain 25 kali, rata-rata pemahaman siswa meningkat sebesar $29,48 \%$ dibandingkan nilai prates.

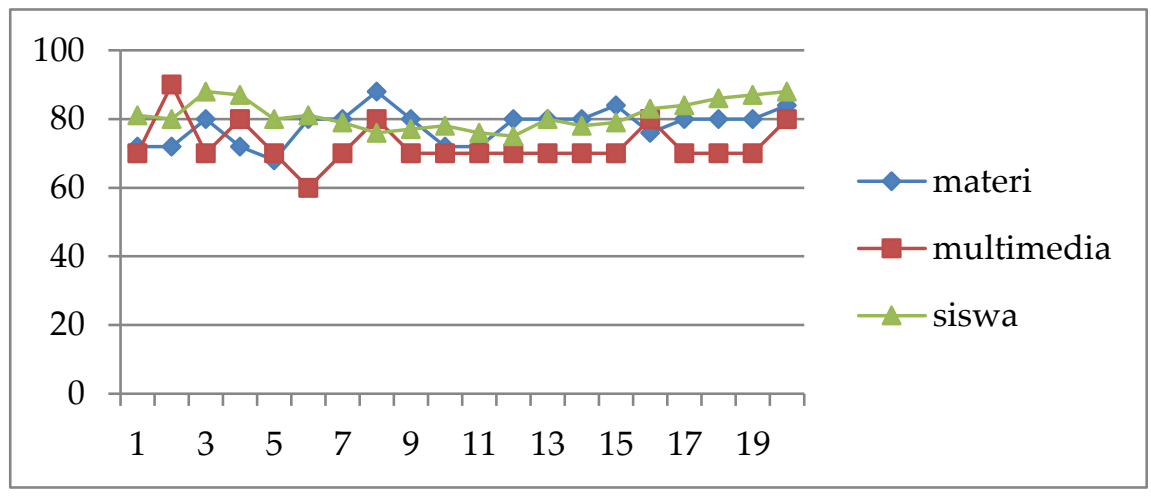

Gambar 8. Hasil Validasi SGMSB

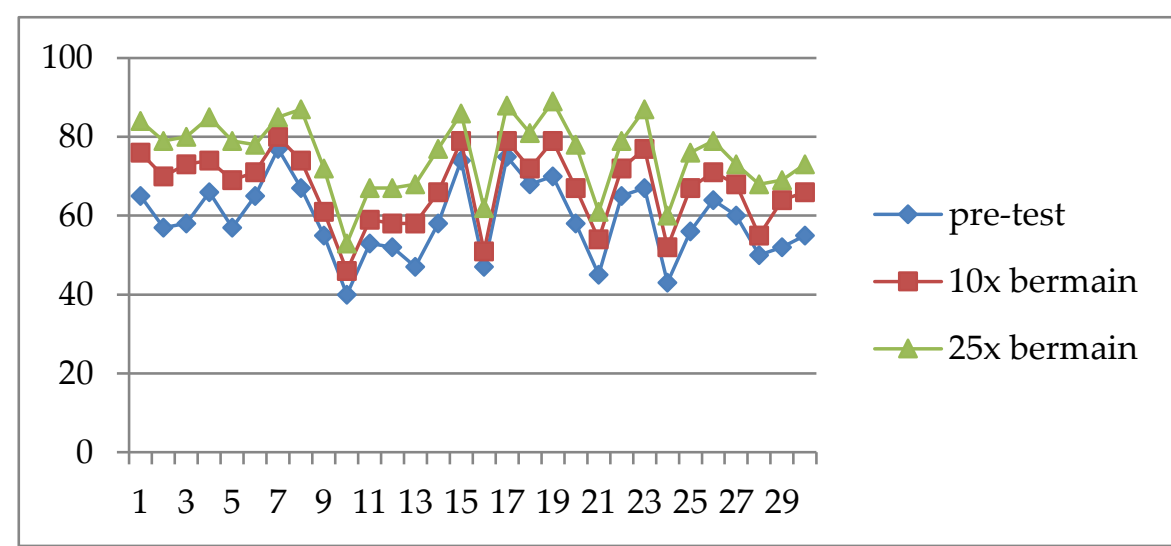

Gambar 9. Hasil uji coba SGMSB pada 30 siswa

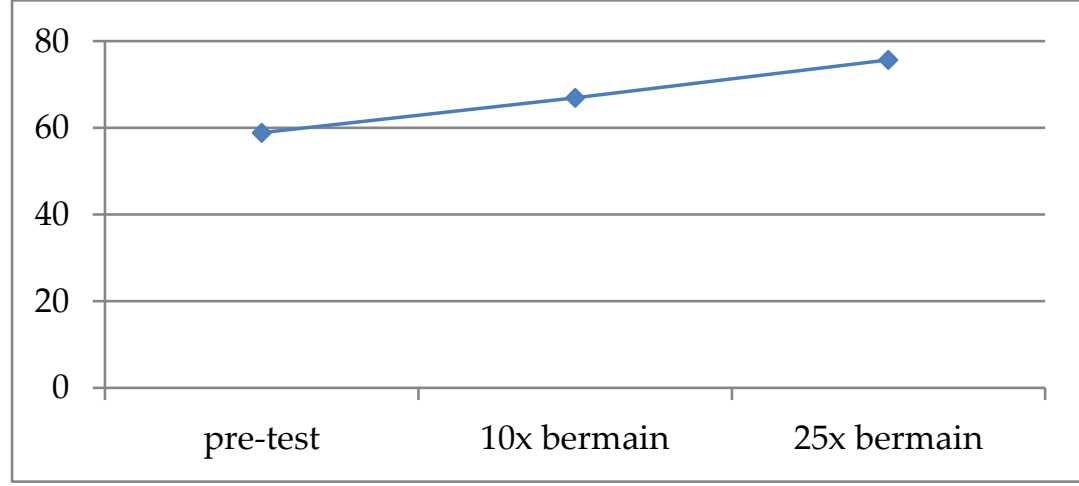

Gambar 10. Peningkatan skor pemahaman siswa

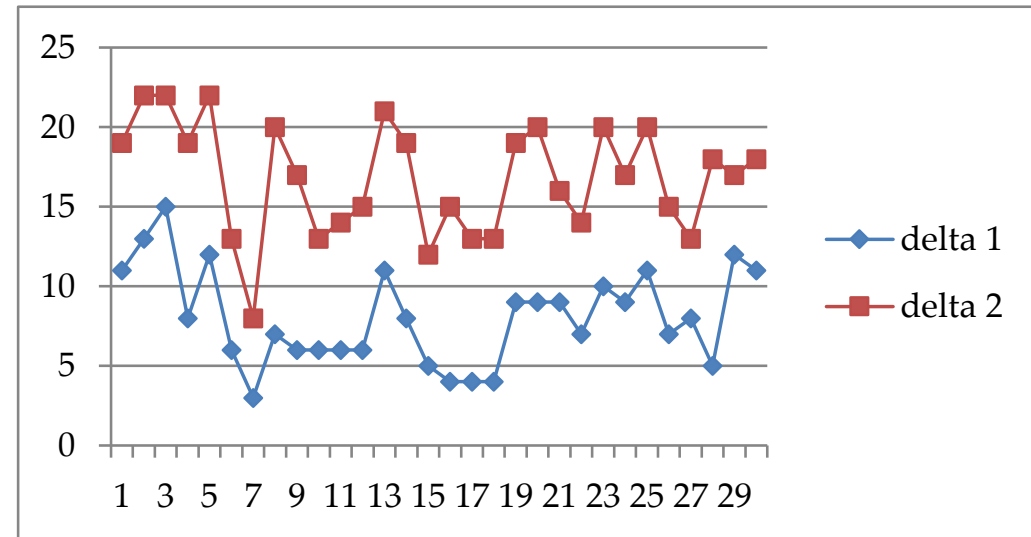

Gambar 11. Selisih skor pemahaman siswa 
Penilaian berdasarkan pemahaman tiap sisi pembelajaran -yaitu aspek kognitif 30\%, afektif $30 \%$, dan psikomotorik $40 \%$ - dilakukan dengan merekam data permainan tiap siswa. Sesuai dengan uraian Tabel 2, jika menjawab benar, siswa memperoleh poin 1. Sebaliknya jika siswa menjawab salah, poin yang diperoleh adalah nol. Poin maksimal untuk aspek kognitif adalah enam karena pertanyaan yang diajukan terdiri dari enam indikator, yaitu $\mathrm{C} 1$ dua indikator, $\mathrm{C} 2$ tiga indikator, dan $\mathrm{C} 3$ satu indikator. Pada sisi afektif, poin maksimal siswa adalah 8, terdiri dari A1 hingga A8. Sedangkan pada sisi psikomotorik, nilai maksimal yang dapat dicapai siswa adalah 9, terdiri dari P1 hingga P9.

Dalam Gambar 12, diperlihatkan peningkatan pencapaian siswa saat prates, setelah bermain 10 kali, dan setelah bermain 25 kali. Dari sisi kognitif, saat prates nilai rata-rata yang dicapai siswa adalah 0,12; setelah bermain 10 kali skor rerata pelajar beranjak menjadi 0,23, kemudian setelah bermain 25 kali skor rerata pelajar membubung menjadi 0,27. Hal ini menunjukkan bahwa sisi kognitif siswa mengalami peningkatan yang siginifikan positif. Dari sisi afektif, saat pretest nilai rata-rata yang dicapai siswa adalah 0,12; setelah bermain 10 kali skor rerata pelajar beranjak ke 0,19, dan setelah bermain 25 kali skor rerata pelajar memuncak menjadi 0,28. Peningkatan ini menunjukkan bahwa sisi afektif juga mengalami perkembangan yang positif. Dari sisi psikomotorik, saat pretest nilai rata-rata yang dicapai siswa adalah 0,16; setelah bermain 10 kali skor rerata pelajar merayap menjadi 0,33 , selanjutnya setelah bermain 25 kali skor rerata pelajar merayap menjadi 0,38. Kondisi ini menyatakan bahwa sisi keterampilan siswa mengalami perbaikan yang bagus.

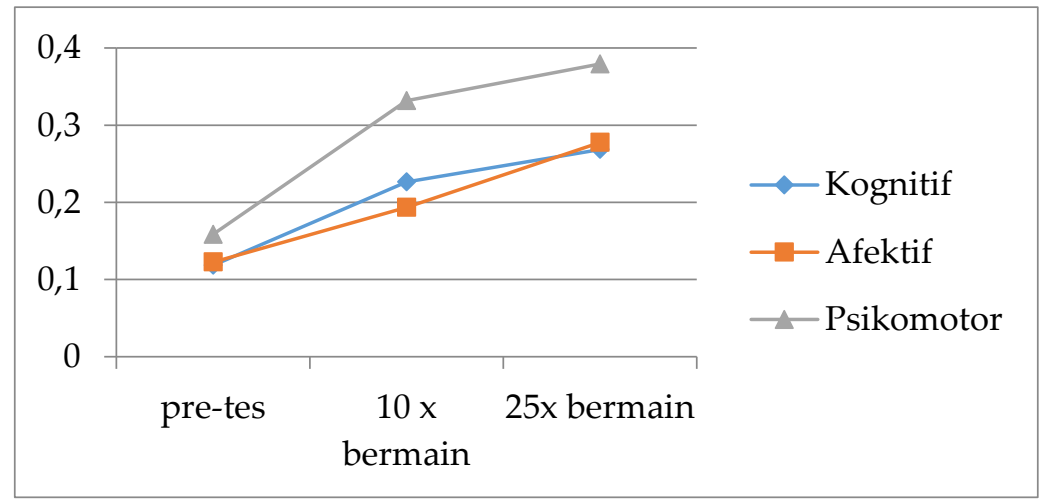

Gambar 12. Peningkatan pemahaman siswa dari aspek kognitif, afektif dan psikomotor

Pada tahap akhir, siswa diminta menjawab beberapa pertanyaan terkait penggunaan game untuk belajar tentang fenomena bencana alam. Pertanyaan yang diajukan terdiri dari 10 pertanyaan terkait kemudahan bermain, misi yang harus diselesaikan, pemahaman perintah, kesenangan belajar menggunakan game, keinginan bermain lagi, pertanyaan yang mudah diingat, kesenangan dengan misi pencarian, penghafalan pertanyaan, permainan tiga dimensi, dan informasi yang membantu pemahaman. Hasil kuesioner menunjukkan bahwa sebagian besar siswa senang belajar menggunakan game dan sangat tertarik dengan game yang disajikan. Beberapa siswa menunjukkan pertanyaan yang diberikan mudah dihafal. Hasil kuesioner diperlihatkan dalam Gambar 13 berikut ini, yang terdiri atas STS = sangat tidak setuju, TS = tidak setuju, $\mathrm{N}=$ netral, $\mathrm{S}=$ setuju, dan SS = sangat setuju.

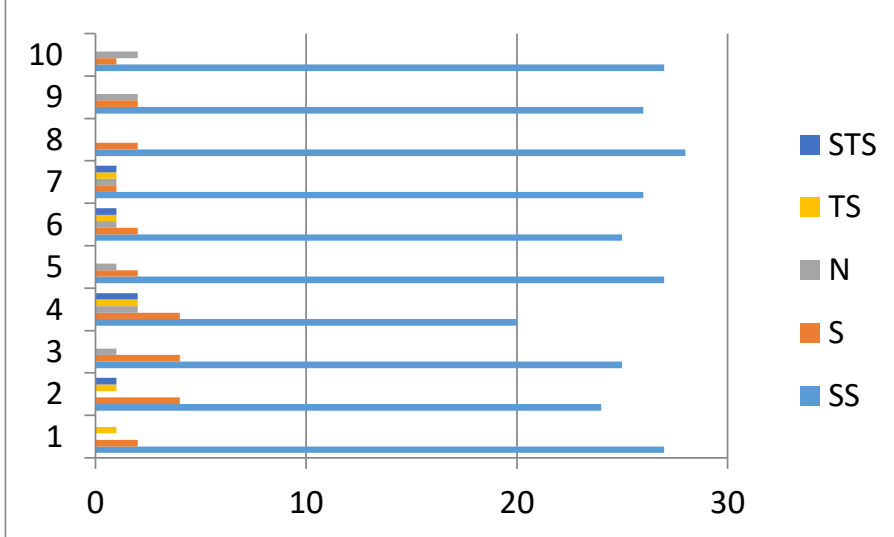

Gambar 13. Kuesioner setelah siswa belajar menggunakan SGMSB 


\section{Kesimpulan}

Dari uraian hasil dan pembahasan sebelumnya, dapat ditarik beberapa kesimpulan, antara lain, validasi yang dilakukan oleh ahli multimedia, guru dan siswa menunjukkan bahwa SGMSB yang dibuat sudah memenuhi sisi edukasi dan hiburan. Hasil uji coba pada 30 siswa menyatakan bahwa terjadi peningkatan yang signifikan positif. Peningkatan yang dicapai siswa setelah bermain 10 kali dan 25 kali terbukti seimbang, karena desain yang diajukan sudah mempertimbangkan tiga aspek Taksonomi Bloom.

Namun, hasil yang telah dicapai masih menunjukkan beberapa kelemahan. Kelemahan itu antara lain dari sisi materi. Materi pertanyaan merupakan pilihan ganda dengan hanya satu jawaban benar sehingga memungkinkan terjadi kebosanan pada sisi pemain. Terdapat juga kemungkinan bahwa saat bermain, siswa memberikan jawaban yang tidak sengaja benar, atau jawaban yang diberikan merupakan hasil jawaban teman, bukan hasil pemikiran siswa. Kemunculan pertanyaan masih bersifat statis sehingga mudah dihafalkan oleh siswa. Skenario permainan masih bersifat statis sehingga terjadi kemungkinan siswa cepat bosan. Perubahan kesulitan permainan masih belum dieksplorasi lebih dalam sehingga pemain mudah menguasai permainan dengan cepat. Jumlah responden yang digunakan masih sedikit sehingga masih terdapat kemungkinan tipe siswa yang bermain bersifat homogen.

Dari pengamatan terhadap kelemahan tersebut, pengembangan selanjutnya dapat difokuskan pada beberapa poin. Misalkan pada sisi materi, pertanyaan yang diajukan akan lebih baik jika pilihan jawaban benar lebih dari satu sehingga kemampuan siswa dapat dikembangkan. Untuk menghindari kemungkinan tidak sengaja menjawab benar, dapat diperbaiki dengan menambah jumlah pertanyaan untuk indikator capaian yang sama. Kemunculan pertanyaan yang statis dapat diatasi dengan menerapkan kecerdasan buatan pada pembangkit pertanyaan sehingga bersifat adapatif berorientasi pada kemampuan siswa. Skenario permainan perlu ditambahkan dengan pembangkit skenario autonomous. Perubahan kesulitan permainan juga perlu dibuat lebih beragam dan dibuat berbeda pada setiap awal permainan. Hal ini dapat dilakukan dengan menanamkan pembelajaran mesin dalam desain Serious Game. Dengan begitu, diharapkan pemain selalu merasa tertantang. Penambahan jumlah responden dari sekolah dasar yang berbeda dapat memberikan keragaman tipe siswa.

Penelitian ini berfungsi sebagai pelengkap metode pembelajaran, terutama pembelajaran tentang kebencanaan dan berfungsi untuk memudahkan akses terhadap literasi tentang kebencanaan karenawilayah Indonesia merupakan kawasan ring of fire (cincin api) yang cenderung rentan terhadap bencana alam.

\section{Referensi}

Ahmad, T. S., \& Hussin, A. A. (2017). Application of the Bloom's Taxonomy in Online Instructional Games. International Journal of Academic Research in Business and Social Sciences, 7(4), 1009-1020.

Callaghan, M., McShane, N., \& Eguíluz, A. G. (2018). Extending the Activity Theory Based Model for Serious Games Design in Engineering to Integrate Analytics. International Journal of Engineering Pedagogy (iJEP), 8(1), 109-126.

Carvalho, M. B. (2016). Serious Games for Learning A model and a reference architecture for efficient game development. Eindhoven, Netherlands: Technische Universiteit Eindhoven. Retrieved from www.drhu.eu/reports/201701-MairaCarvelho-SeriousGamesForLearning.pdf

Doroteo, H. J. (2015). Philippines: Disaster risk profile and Disaster Risk Reduction (DDR) framework: Natural calamities. Asturias, Spain: University of Oviedo.

Gao, Z., Ma, D., Guo, X., Wang, W., \& Wang, Z. (2019). The Comprehensive Assessment Method of Concrete Damage after Disastrous Fire Based on Game Theory-Normal Cloud Model. Mathematical Problems in Engineering.

Hamlen, K. R. (2011). Children's choices and strategies in video games. Computers in Human Behavior, 27(1), 532-539.

Hanes, L., \& Stone, R. (2018). A model of heritage content to support the design and analysis of video games for history education. Journal of Computers in Education, 1-26. 
Haring, P., Warmelink, H., Valente, M., \& Roth, C. (2018). Using the Revised Bloom Taxonomy to Analyze Psychotherapeutic Games. International Journal of Computer Games Technology.

Kurniawan, R., Mahtarami, A., \& Rakhmawati, R. (2017). GEMPA: Game Edukasi sebagai Media Sosialisasi Mitigasi Bencana Gempa Bumi bagi Anak Autis. JNTETI, 6(2), 174-183.

nextgenscience. (2013, May). Fourth Grade. Retrieved from Next Generation Science Standards: https://www.nextgenscience.org/sites/default/files/4\%20combined\%20DCI\%20standardsf.pdf

Pourabdollahian, B., Taisch, M., \& Kerga, E. (2012). Serious Games in Manufacturing Education: Evaluation of Learners' Engagement. Procedia Computer Science, 15, 256-265.

Westera, W. (2017). How people learn while playing serious games: A computational modelling approach. Journal of Computational Science, 18, 32-45.

Wibowo, A., Insani, A., \& Suwardi, B. N. (2017). Modifikasi Pattern Informatics untuk Prediksi Hotspot Aktivitas Seismik pada Gempa di Pulau Jawa. JNTETI, 6(2), 121-126.

Wszolek, Z. K., \& Pfeiffer, R. F. (2015). Annual Report 2014. Parkinsonism and Related Disorders, 21(2015), 430.

Yuhana, U. L., Yuniarno, E. M., Nugroho, S. M., Rochimah, S., \& Purnomo, M. H. (2017). Penggalian Pola Kemampuan Peserta Ujian Berbasis Klaster untuk Penentuan Aturan Sistem Penilaian. JNTETI, 6(4), 445-454. 